\title{
DEBIUTY
}

Forum Pedagogiczne $10(2020) 2$

Wpłynęło: 29.03.2020 Zatwierdzono do druku: 24.06.2020 DOI: $10.21697 /$ fp.2020.2.21

\author{
ANNA MENTEL* \\ Warszawa, Polska \\ ORCID ID: https://orcid.org/oooo-ooo2-5552-40oX
}

\section{WIZUALIZACJA JAKO SYMULACYJNE KREOWANIE SIEBIE W MEDIACH SPOŁECZNOŚCIOWYCH}

\begin{abstract}
Streszczenie: Celem artykułu jest przedstawienie sposobów wizualnej prezentacji siebie przez młodych ludzi na profilu Facebook. Na podstawie teorii symulakry Jeana Baudrillarda założono, że prezentacje te służą symulacyjnemu tworzeniu własnej tożsamości. W badaniu posłużono się metodą netnograficzną, ze szczególnym uwzględnieniem etnografii wizualnej. Zaprezentowane badania wpisują się w problematykę związaną z budowaniem tożsamości współczesnej młodzieży i trendami kultury ponowoczesnej. Wykazano, że treści wizualne stanowią nie tylko oderwany od rzeczywistości element kreowania siebie przez młodych ludzi, lecz także obraz fikcyjnej rzeczywistości. Uwidocznia się to zwłaszcza w wirtualnych formach aktywności i treściach zamieszczanych przez młode osoby $\mathrm{w}$ internecie.
\end{abstract}

Słowa kluczowe: wizualizacja; tożsamość; symulakra; kultura upozorowana.

\section{Wprowadzenie}

W życiu współczesnej młodzieży przestrzeń internetu służy nie tylko do komunikowania się, lecz także do tworzenia własnej tożsamości. Z tej perspektywy można powiedzieć, że internet stał się „miejscem” dorastania, w tym również szeroko rozumianego dojrzewania. W wirtualnej rzeczywistości, która współcześnie nie ma już charakteru jedynie pasywnego, lecz interaktywny, dużą rolę odgrywa obraz. $Z$ jednej strony jest on nośnikiem informacji niewerbalnych czy pozawerbalnych,

* Mgr Anna Mentel, absolwentka Wydziału Nauk Pedagogicznych Uniwersytetu Kardynała Stefana Wyszyńskiego w Warszawie; e-mail: a-mentel@wp.pl. 
z drugiej zaś medium kreowania siebie przez wizualizację. Ta druga funkcja obrazu otwiera przed młodymi (i nie tylko młodymi) ludźmi nowe możliwości korzystania z przestrzeni internetu w celu poszukiwania własnej tożsamości. Stojąc na granicy dwóch światów - realnego (off-line) i wirtualnego (on-line) - dorastający znajdują się nierzadko w sytuacjach potęgujących ich trudności związane z dorastaniem i dojrzewaniem.

W tym artykule prześledzono wybrane przejawy wirtualnej aktywności trójki młodych użytkowników Facebooka, celem określenia, w jaki sposób wykorzystują oni wirtualną przestrzeń do kreowania siebie za pomocą obrazu. Zbyszko Melosik tłumaczy dominującą współcześnie wśród młodzieży zasadę „robić wrażenie” w następujący sposób: „[N]ic nas nie obchodzi, kim naprawdę jesteś, ważne jak się prezentujesz" (2013, s. 8). Nieodparcie nasuwa to na myśl teorię symulakry Jeana Baudrillarda, która pomaga zrozumieć wszechobecne dzisiaj zjawisko pozorowania.

Prezentowany artykuł składa się z czterech części. W pierwszej przedstawiono rozważania teoretyczne dotyczące zarówno wieku adolescencji jako specyficznej fazy rozwojowej, jak i Baudrillardowskiej teorii symulakry. W drugiej części omówiono kwestie metodologiczne. Po czym w trzeciej części zaprezentowano przeprowadzone badanie i jego wyniki. Na zakończenie sformułowano wnioski odnośnie działań pedagogicznych ukierunkowanych na pomoc młodym ludziom w poszukiwaniu własnej tożsamości w przestrzeni internetu.

\section{Tożsamość-cyberprzestrzeń-teoria symulakry}

Dojrzewanie biologiczne rozpoczyna okres formowania się tożsamości młodego człowieka w znaczeniu jego poczucia odrębności wobec innych i świadomości siebie samego. W psychologicznych koncepcjach rozwoju, takich jak J. Piageta (1998), E. Eriksona (1982) czy L. Kohlberga (1984), wyodrębnia się etapy resp. stadia, które przebywa jednostka w drodze do osiągnięcia pełni rozwoju osobowego. Koncepcje te określają uniwersalne mechanizmy postępu w zakresie życia psychofizycznego i kreowania własnej tożsamości. W ich świetle osiągnięcie dojrzałości płciowej uznaje się za kluczowe zadanie wieku adolescencji.

Młody człowiek w okresie dojrzewania poszukuje wiedzy o samym sobie, podpatruje przedstawicieli różnych ról społecznych, rozbudowuje zakres swojego samostanowienia. Z perspektywy psychospołecznej okres ten należy traktować jako pełen zmian jakościowych, które zachodzą zarówno na zewnętrz, jak i wewnątrz dorastającego (Oleszkiewicz, Senejko 2013; Obuchowska 2014; Czerwińska-Jasiewicz 2015). Jednostka rozwija w sobie poczucie własnej tożsamości, a uzyskując odpowiedź na pytanie, kim jestem, staje się człowiekiem dojrzałym i „mimo zachodzących nieustannie zmian, pozostaje tym samym, konkretnym, określonym bytem" (Kaczorowski 2006, s. 148).

Tożsamość powstaje w polu napięć między autopercepcją a obiektywizacją siebie wobec społeczności, takich jak rodzina, grupa rówieśnicza i środowisko społeczne. 
Nie jest ona niczym stałym ani ustanowionym z góry, lecz należy ją rozpatrywać jako „fenomen rozwijający się, dynamiczny, otwarty na ustawiczną kreację i stawanie się" (Pilch 2007, s. 754). To powoduje, że osoba konstytuuje swoją tożsamość przez nabywanie poczucia sprawstwa i ponoszenie odpowiedzialności za własne czyny. W tym kontekście istotną rolę odgrywa umocowanie w stabilnych relacjach, tak indywidualnych, jak i społecznych, gdyż „bez trwałego rdzenia (mała ojczyzna, ziemia rodzinna, pamięć historyczna), bez wyraźnego samookreślenia we własnej odrębności powstają trudności w zakresie [kształtowania tożsamości - dop. A.M.]" (Pilch 2007, s. 754). Niebagatelną funkcję ma tutaj do spełnienia szeroko rozumiana tradycja i przekaz wartości.

Kształtowanie własnej odrębności i współzależności obejmuje również dojrzewanie płciowe i tożsamość osobową w tym zakresie. We wskazanych powyżej koncepcjach psychologiczno-rozwojowych twierdzi się, że jedno z najważniejszych zadań okresu adolescencji polega na dobrowolnym przyjęciu przez jednostkę roli męskiej resp. żeńskiej i posługiwanie się własnym ciałem zgodnie z jego determinacją wynikającą z natury. Tak więc poczucie przynależności do danej płci wiąże się z procesami psychologicznymi. Na prawidłowy przebieg rozwoju tożsamości płciowej oddziałuje identyfikacja z rodzicem (Brzezińska 2016). Krystalizowanie się tej więzi wiąże się z prawidłowym procesem wychowania w rodzinie. Rodzice są pierwszymi osobami, którzy wzmacniają i utwierdzają rozumienie siebie. Współcześnie daje się zaobserwować trudności w tym względzie. Wiążą się one z zawirowaniami oczekiwań społecznych i negowaniem sfery biologicznej, ponadto z negocjacyjnym traktowaniem siebie w pełnieniu ról społecznych.

Na pojmowanie płci oprócz czynników biologicznych i społecznych oddziałuje dyskurs między naturą a kulturą. Wskazuje się tutaj na przestrzeń wolności dotyczącą wyboru własnej płci. Granice tego wyboru zależą od koncepcji człowieka i są przedmiotem ścierania się opozycyjnych stanowisk. Nie może dziwić, że u niektórych młodych ludzi prowadzi to do eksperymentowania w zakresie bycia kobietą lub mężczyzną. Jak twierdzi Janusz Surzykiewicz, „rywalizujące ze sobą koncepcje człowieka, świata wartości, znaczenia rodziny, znajdują swoje odzwierciedlenie w modelach ról kobiecych [i męskich - dop. A.M.]” (2012, s. 10), które stały się przedmiotem negocjacji. W tym kontekście dużą popularnością cieszy się termin gender, który werbalizuje nastawienie, w centrum którego jest kulturowe rozumienie płciowości. Płeć kulturowa (gender) tworzy nadbudowę wobec płci biologicznej, która daje się rzekomo modyfikować zgodnie z wolą podmiotu (Titkow 2002). Na tym tle nie mówi się w przestrzeni publicznej o odkrywaniu własnej płciowości i jej afirmowaniu, lecz o kreowaniu i interpretowaniu biologicznej natury człowieka.

Z nakreślonym powyżej problemem łączą się wyzwania epoki postmodernistycznej. W kontekście kształtowania (się) tożsamości adolescentów szczególnego znaczenia nabiera zjawisko globalizmu (Cybal-Michalska 2006). W odniesieniu do niego Z. Melosik (2003) stwierdza, że socjalizacja młodzieży przebiega współcześnie w kręgach popkulturowych, w których hołduje się zachowaniom 
konsumpcjonistycznym. Pierwszoplanową rolę odgrywa w nich kultura medialna, która przejawia się w „płynnej tożsamości” (Giddens 2008). Oznacza to, że jednostka uzurpuje sobie prawo do samodzielnego definiowania tego, kim jest i kim chce być. W socjologii edukacji prezentowane zjawisko określa się mianem „przesunięcia socjalizacyjnego" (Kwieciński, Witkowski 1990). Źródłowo wiąże się ono z fenomenem internetu. Dzięki niemu wirtualny świat staje się „,doradcą" młodych ludzi i globalnym „nauczycielem” norm i wartości. Trudność polega jednak na tym, że ów nauczyciel zaleca konstruowanie własnej tożsamości w swobodnej ekspresji. W związku z tym nasuwa się pytanie, jak jego rady są traktowane przez młodych ludzi. Innymi słowy, czy kierują się nimi, czy też nie.

Badania na temat aktywności młodzieży w cyberprzestrzeni wskazują na to, że priorytetowe znaczenie ma dla nich udostępnianie treści na portalach społecznościowych ${ }^{1}$ Z pomocą indywidualnych profili na portalach młodzi ludzie komunikują się z wirtualną społecznością i równocześnie wytwarzają własny wirtualny wizerunek. Bez wątpienia najbardziej rozpowszechnionym portalem jest Facebook. Chęć bycia widocznym staje się wewnętrzną potrzebą, która nierzadko przeradza się $\mathrm{w}$ dążenie do zdobycia wirtualnej popularności (Szpunar 2016). Towarzyszy temu niebezpieczeństwo spłycenia kontaktów i ubożenia relacji bezpośrednich - face to face. W tym kontekście obrazy, np. fotografie, otrzymują nową funkcję w internecie. Przestają służyć dzieleniu się z przyjaciółmi i znajomymi swoimi spostrzeżeniami i przeżyciami, a stają się narzędziami do dezorientowania wirtualnej społeczności. Manifestuje się ona $\mathrm{w}$ działaniach polegających na rozmyślnym tworzeniu fikcyjnych obrazów w celu wywołania u odbiorców pożądanych reakcji. W tym zastosowaniu obraz zawiera komunikat, który ma wpłynąć na odbiorcę przekazu. Tworzona kultura wizualna staje się przestrzenią pełną manipulacji i sztuczności.

W świetle powyższych rozważań koncepcja symulakry, którą Jean Baudrillard przedstawił w opracowaniu pt. Symulakry i symulacje (2005), ukazuje się z nową mocą i aktualnością. Francuski filozof skupia uwagę na procesach społecznych i zjawisku symulacji. To ostatnie przypisuje społeczeństwu postmodernistycznemu jako jego cechę charakterystyczną. Symulacja polega na wytwarzaniu pseudorzeczywistości, z której wyeliminowano realność i w której powiela się puste znaki, tzn. niemające żadnych rzeczywistych punktów odniesienia. Taką sztuczną i celowo wytworzoną rzeczywistość J. Baudrillard opatruje mianem „hiperrzeczywistości”. Dominujące są w niej czynności symulacyjne, w trakcie których pozoruje się

$1 \mathrm{~W}$ tym kontekście należy przywołać badania dotyczące aktywności młodzieży w internecie. Najnowszej wiedzy w tym zakresie dostarcza raport Instytutu Badawczego NASK Nastolatki 3.o. (2017). Korzystanie ze świata on-line związane jest z zagrożeniami, które podejmuje w badaniach Józef Bednarek (2012; 2014; 2015). Typologię zagrożeń wynikających z nieumiejętnego korzystania z technologii cyfrowych opracował Jacek Pyżalski (2018) na podstawie projektu $E U$ Kids Online. Cyberprzestrzeń jako „miejsce” pełniące funkcje edukacyjne opisuje Maciej Tanaś (2015; 2016). 
działania, imituje wzory i/lub zafałszowuje rzeczywistość. Obiektywizację tych czynności omawiany autor oznacza terminem „symulakrum”. W terminologii J. Baudrillarda jest to znak, któremu brakuje punktu odniesienia w realnej rzeczywistości. Jego główne zadanie polega na ucieleśnianiu w wirtualnym świecie wspomnianych czynności symulacyjnych. Przez to symulowanie wytwarza na swoje potrzeby sztuczną rzeczywistość, która w bardzo prosty sposób uobecnia się na ekranie komputera.

Wspomniana „hiperrzeczywistość” rozrasta się przez dodawanie coraz to nowych, pustych znaków, które wchodzą w konflikt z realną rzeczywistością. J. Baudrillard uważa, że „broniąc się przed hipotezą o radykalnym złudzeniu świata, za wszelką cenę usiłując ją obalić [...] dążymy do pełnego urzeczywistnienia świata, chcemy nadać mu realność, zmusić do istnienia, przegnać zeń pozory, wydobyć sens, odebrać mu formę i zastąpić ją formułą" (2005, s. 25). Te zdania tłumaczą współczesną rzeczywistość, która tworzy się z różnorodności znaczeń. Prowadzi to do iluzji tymczasowości i przyczynia się do multiplikowania owych znaczeń.

Teoria symulakry otwiera możliwość interpretacyjnego zrozumienia przemian zachodzących we współczesnym świecie, w szczególności pod wpływem nowoczesnych technologii komputerowych. Na gruncie pedagogiki polskiej Michał Głażewski (2018) wykorzystał ją do zdemaskowania pozorowanych działań podejmowanych w edukacji. W prezentowanym tekście dostarcza ona podstaw teoretycznych do odczytania wizualizacji w internecie. $Z$ pomocą przysłowiowego kliknięcia można przenieść się w świat fikcji. Jest to świat Baudrillardowskiej hiperrzeczywistości, w której „obrazy zatraciły kontakt ze swoją matrycą” (Gondek 2016, s. 440). Co więcej, stały się narzędziem wizualnej prezentacji siebie (Rogowski 2014) i konstruowania własnego wizerunku.

\section{Założenia metodologiczne badania}

Celem badania było poznanie sposobów wizualnego prezentowania siebie w mediach społecznościowych przez trzy nastoletnie osoby, wychowanki placówki socjoterapeutycznej. Badanie zostało przeprowadzone przy użyciu metody netnograficznej (Jemielniak 2012; Kozinets 2012). Metoda ta ukierunkowana jest na „formy komunikacji zapośredniczonej przez komputer jako źródło danych” i służy „do etnograficznego zrozumienia i przedstawienia wybranych zjawisk kulturowych czy społecznych" (Kozinets 2012, s. 93).

Badanie netnograficzne zalicza się do strategii jakościowych, w których uwaga badacza koncentruje się na obserwowaniu działań i interpretowaniu ich znaczeń. Zostało ono zrealizowane przez obserwację uczestniczącą ukrytą (Konecki 200o). Powodem takiego postępowania badaczki była chęć dotarcia do naturalnego środowiska osób badanych. Do wydobycia ze zgromadzonego materiału znaczeń wykorzystano analizę dyskursu (Konieczna 2014) i interpretację dyskursywną (Sztompka 
2005). Wymienione metody umożliwiły pogłębione zrozumienie zaobserwowanych działań podejmowanych przez badane osoby na swoich profilach Facebookowych.

Dane zgromadzone w trakcie badania zostały pozyskane z profili na Facebooku trzech nastolatek. Kluczowe znaczenie miała obserwacja sposobów wizualizowania siebie. Badane osoby komunikowały się na swoich profilach przede wszystkim przez zamieszczanie zretuszowanych fotografii. Piotr Sztompka określa mianem dyskursu wizualnego „proces negocjacyjny, w którym artykułują się znaczenia obrazów [...] i zmierzają do ujawniania, do kogo zdjęcie jest adresowane i kto jest rzeczywistym adresatem" (2005, s. 92). W omawianym badaniu fotografie potraktowano jako podstawowe źródło wiedzy o właściwościach osób. Istotne było dotarcie przez to środowiska społecznego, w którym funkcjonują nastolatki i lepsze jego zrozumienie.

Fotografie zamieszczone na Facebooku nabierają charakteru etnograficznego wówczas, gdy badacz „zdefiniuje je tak, dzięki interpretacji i kontekstowi” (Pink 2009, s. 35). W związku z tym przy analizowaniu i intepretowaniu dokumentów fotograficznych posłużono się następującymi wskazówkami: (1) miejsce prezentowania siebie przez badaną osobę; (2) treści zawarte w przekazie wizualnym i jego adresaci oraz (3) sposoby wizualizowania siebie.

Badane nastolatki nie zostały poinformowane o tym, że są adresatkami czynności badawczych, niemniej wszystkie pozyskane materiały były dostępne w otwartej cyberprzestrzeni. Ponieważ badaczka nie miała bezpośredniego dostępu do ich profili na Facebooku, zwróciła się z prośbą do koleżanek z tej samej placówki socjoterapeutycznej o pomoc w zgromadzeniu materiału badawczego. Dzięki nim udało się jej dotrzeć do omówionych poniżej materiałów. Poza tym odbyła szereg wywiadów swobodnych z koleżankami badanych, co okazało się pomocne przy wydobyciu i zrozumieniu perspektywy rówieśniczej. Tematyka tych wywiadów oscylowała wokół fotografii i postów udostępnianych przez badane osoby na Facebooku, z których pozyskano screenshoty, dostarczone przez ich koleżanki. Podczas wywiadów badaczka pytała respondentki, dlaczego właśnie te fotografie uznały za interesujące i w jaki sposób je odczytują. Podczas wywiadów prosiła rozmówczynie o nadanie fotografiom odpowiednich tytułów.

Tak prowadzona pośrednia obserwacja i rozmowy z koleżankami badanych dały możliwość zapoznania się z perspektywą patrzenia na wirtualne formy aktywności i treści zamieszczane w internecie. Niebagatelne było odszyfrowanie specyficznego języka stosowanego w wirtualnej społeczności, do której należały badane nastolatki i przyjrzenie się roli tego języka w budowaniu tożsamości społecznej w internecie.

W celu zobiektywizowania uzyskanych danych badaczka przeprowadziła dyskusję panelową z grupą uczniów z konkretnego liceum ogólnokształcącego. Uczniom tym nie była znana tożsamość badanych nastolatek. Przedmiotem dyskusji były trzy fotografie, które znajdują się w centrum niniejszego opracowania.

Przedsięwzięcie badawcze było realizowane od listopada 2019 do kwietnia 2020 roku. W jego trakcie badaczka prowadziła dziennik, w którym notowała swoje 
spostrzeżenia i uwagi z wywiadów z koleżankami badanych nastolatek i z grupą młodzieży licealnej. Wypisy zaczerpnięte $\mathrm{z}$ tego dziennika zaznaczono poniżej sygnaturą „NT” (notatka tekstowa), opatrzoną datą dzienną. Całość materiału znajduje się w prywatnym archiwum badaczki.

\section{Wyniki badania}

Przy analizowaniu materiału badawczego skoncentrowano się na danych nietekstowych zawartych $\mathrm{w}$ fotografiach. Celem było uchwycenie sposobów wizualnego prezentowania siebie przez nastolatki. W postępowaniu badawczym chodziło o dotarcie do wiedzy społecznej i kulturowej przekazywanej za pośrednictwem fotografii. Dzięki temu uzyskano swoisty portret młodego człowieka, który mówiąc o sobie, posługuje się współcześnie przekazem wizualnym.

Ze zgromadzonego materiału badawczego wyselekcjonowano do analizy trzy fotografie - po jednej od każdej z badanych nastolatek. Problem wizualizacji ujęto z pomocą trzech kategorii: (1) doznaniowość; (2) „zdarzenia wizualne” i (3) audytorium/„reżim patrzenia”. Doznaniowość należy rozumieć jako emocjonalny przekaz, mający na celu wywołanie pożądanej reakcji u odbiorcy. Z perspektywy teorii Baudrillarda doznaniowość służy do pozorowania siebie. Wiąże się z nią fragmentaryczność i operowanie symbolami zaświadczającymi o przynależności do określonego środowiska (subkultury). Kategoria ta zawiera odpowiedź na opinie i oceny wyrażane przez wirtualnych znajomych; wzmaga i potęguje obserwowany proces autokreacji wśród badanych. Warto zwrócić uwagę na fakt, że osoby badane na fotografiach celowo kamuflowały „swoje prawdziwe oblicze, podkreślając radykalną zmianę tożsamości, bo to «kręci» innych" (NT-2019-10-02). W tym ujęciu fotografie traktowane są jako nośnik komunikatu nietekstowego, który skierowany jest do innych, a nie jako niewymuszona i spontaniczna ekspresja siebie samego.

Przez „zdarzenia wizualne” rozumie się narzędzia konstruowania wizerunku. Uwzględniają one określone sposoby prezentowania siebie. W trakcie realizacji badania okazało się, że każda z trzech nastolatek wizualizowała siebie dość schematycznie. Ta monotonia w prezentowaniu siebie odwoływała się przede wszystkim do wyglądu zewnętrznego. Przekaz wizualny bazował na ubiorze, który cechował męski styl. Dodatkowo wzmacniała go przyjmowana przez osoby badane poza ciała. W pozie tej nastolatki nawiązywały do społeczno-kulturowego stereotypu bycia mężczyzną. Dzięki badaniu okazało się, jak istotnym narzędziem w konstruowaniu własnego wizerunku są zainteresowania badanych. Przykładowo jedna z nich interesuje się motoryzacją i dlatego najczęściej umieszczała na swoim Facebooku fotografie z tym związane.

Audytorium określane jest jako grupa społecznego odbioru, w której występują reguły nazwane „reżimem patrzenia”. Reguły te wytyczają społeczno-kulturowy sposób patrzenia i odgrywają istotną rolę przy zdobywaniu społecznego uznania i popularności. Polega to na „obczajaniu siebie, szukaniu w wyszukiwarkach 
interesujących profili” (NT-2019-10-02), odznaczających się ciekawym wyglądem i oryginalnością. Warto podkreślić, że świadomość wywierania wpływu na audytorium, wzmaga pozorowanie siebie. W tym układzie wzajemnej zależności powstawało negocjacyjnie to, co badane nastolatki przedstawiały na swoich profilach.

Jak wspomniano powyżej, do dogłębnej analizy wyselekcjonowano trzy fotografie prezentujące każdą z badanych osób. Ponieważ w tym artykule nie ma możliwości przedrukowania owych fotografii, konieczny jest ich opis, który zawiera $\mathrm{w}$ sobie pewne elementy interpretacji.

Fotografia pierwsza przedstawia 16-latkę. Jest to forma autoportretu (selfie). Na pierwszy plan wysuwa się twarz badanej, w której są „doczepione” elementy awatara zwierzęcego: uszy, nos i język. W odczytaniu tego zdjęcia wskazówkę daje komentarz koleżanki badanej: „zasłanianie prawdy o sobie wynika z kompleksów na temat swojego wyglądu [...] trzeba dobrze zaprezentować się na zdjęciu i niekoniecznie zgodnie z prawdą" (NT-2019-12-01). Warte uwagi są części ubioru mieszczące się w kanonie mody męskiej. Tytuł nadany przez koleżanki w trakcie swobodnego wywiadu brzmiał: „Imitacja”. Co wskazuje na sztuczność i ukazywanie nieprawdy o sobie.

$\mathrm{Na}$ drugiej fotografii znajduje się pierwsza $\mathrm{z}$ dwóch 18-latek. Jej postać została ukazana na tle samochodu. Fotografia wiąże się z zainteresowaniem motoryzacją. Warto zwrócić uwagę na ubiór. Szeroka kurtka i spodnie sportowe komponują się odpowiednio z typowo męską fryzurą. Ręce w kieszeni i mocne oparcie o samochód, a także spojrzenie w dal zdają się sugerować obojętność, alienację. Potwierdzeniem tego jest tytuł nadany przez jedną z koleżanek: „Wszystko jedno”. Pod fotografią znajduje się napis: „Tyle lat edukacji, a nikt nie nauczył nas pokochać samych siebie i dlaczego to takie ważne" (NT-2019-10-24). Słowa te mogą wskazywać na „głód” miłości i potrzebę akceptacji własnej osoby.

Fotografia trzecia przedstawia drugą 18-latkę. Jest to również selfie. Tło wydaje się nieistotne, a wskazuje to na niedbale ucięty fragment schodów z tyłu. Tak jak w obu poprzednich przypadkach cała uwaga skupia się na wyglądzie zewnętrznym osoby. Dominuje w nim mocna męska stylizacja. Wyjaśnienia powodów tego stanu rzeczy dostarcza tytuł: „Lans”, który tej fotografii nadały koleżanki. Słowo to w żargonie młodzieżowym oznacza postawę obnoszenia się, celebrowania siebie samego i eksponowania własnego „Ja”. Poza dziewczyny przedstawionej na zdjęciu epatuje pewnością siebie.

Analiza materiału badawczego polegała na wyodrębnieniu treści wizualnych, które są adresowane do z góry określonej publiczności. W tym celu skonfrontowano wpisy zamieszczone przez badane nastolatki na ich profilach Facebooka z odczytaniem tych treści przez adresatów, którymi były koleżanki z ośrodka socjoterapeutycznego i grupa młodzieży licealnej. Odczytanie sposobów odbierania treści wizualnych przeprowadzono w odniesieniu do dwu wymiarów: (1) wewnętrzny obszar odbioru tworzony przez komentarze „wirtualnych znajomych” 
na Facebooku i (2) zewnętrzny obszar odbioru, który stanowił zobiektywizowanie zaprezentowanych przez nastolatki treści nietekstowych.

Wewnętrzny obszar odbioru tworzony jest przez umieszczanie komentarzy „wirtualnych znajomych” pod fotografiami badanych. Dla zobrazowania charakteru wpisów warto przywołać dwa przykłady: „kochany mężu, wyglądasz cudnie! Kocham! Czekam na kolejną fotkę”, „ślicznie wyglądasz i coraz bardziej mnie zaskakujesz!" (NT-2019-11-30). Oba wpisy mają charakter emocjonalny. Komentowanie sprawia, że „wirtualni znajomi” wchodzą w "grę pozorów” i eksperymentują wraz $z$ autorkami fotografii. Prezentowanie siebie w internecie jako mężczyzn wzmacnia pozytywny odbiór i uczuciowe wyznania innych. Wyodrębniony obszar zwraca uwage przez to, że „aktywność na FB jest dopasowana do innych” (NT-2020o1-16). Komentarz jednej z koleżanek badanych świadczy, że wymiar wirtualnej aktywności związany jest z reakcją publiczności. Adresaci utwierdzają przyjmowaną kreację, reagując na dostarczane przekazy wizualne. Konstruowanie swojego wizerunku adresowane jest do „wirtualnych znajomych”. Pokazuje to tendencję młodych użytkowników medium społecznościowego do uzewnętrzniania uczuć i szukania doznań w osobistych zwierzeniach. Daje się w tym zauważyć „modę” na przekraczanie granicy prywatności w treściach dostępnych w internecie.

Zewnętrzny obszar odbioru tworzony jest przez wypowiedzi koleżanek z placówki socjoterapeutycznej oraz grupę młodzieży licealnej. Koleżanki badanych interpretowały wirtualną aktywność nastolatek, używając następujących określeń: „Szokowanie”, „Zwrócenie uwagi na siebie”, „sposób wyrażania siebie”, „ekshibicjonizm" (NT-2020-01-14). W tych wypowiedziach zwraca się uwagę na celowe kreowanie siebie w internecie. To kreowanie staje się swoistym manifestem młodych ludzi. Koleżanki badanych osób zauważają, że chcą one „zaistnieć” przez konstruowanie fikcji. Tworzenie wizerunku dokonuje się na potrzeby widowni i z chęci bycia obserwowanym.

Drugim zakresem w powyżej kategorii są wypowiedzi młodzieży licealnej, która nie znała badanych nastolatek. W wypowiedziach tych dało się wyróżnić trzy podejścia do samokreacji. Pierwsze podejście cechowało zrozumienie symulacji. Młodzież wyrażała swój stosunek do prezentowanych treści w słowach: „wykreowanie postaci dla znajomych”, „przekraczanie granic prywatności”, „ukrywanie swoich niedoskonałości pod płaszczykiem imitacji”, „wyrażanie odmienności i swojego stylu" (NT-2020-02-15). Przytoczone fragmenty wypowiedzi świadczą, że wizerunek prezentowany z pomocą fotografii staje się narzędziem do kreowania siebie. Daje też możliwość zaspokojenia podstawowych potrzeb, takich jak akceptacja, poczucie przynależności, bycie zauważonym, zdobycie uznania. Wydaje się, że część młodzieży uczestniczącej w analizie fotografii zrozumiała wirtualną symulację tworzoną przez badane i oczytała konstruowanie obrazu siebie jako manipulację.

Drugim podejściem było stanowisko obojętności. Wyrażały je takie słowa, jak: „te zdjęcia są bez sensu”, „nie obchodzi mnie to, co tam jest”, „to ich sprawa”, 
„każdy wstawia, co chce” (NT-2020-02-15). Uczestnicy spotkania nie okazywali zainteresowania ani gotowości zapoznania się z fotografiami. Być może wynikało to stąd, że badane nastolatki nie są ich koleżankami. A może dlatego, że treści zamieszczane w internecie uważane są za prywatne informacje, których nie należy analizować na forum publicznym.

Ostatnim podejściem wyłonionym przez badaczkę z wypowiedzi młodzieży licealnej była krytyka. Część młodzieży w ten właśnie sposób reagowała na treści zawarte w przedstawionych im fotografiach. Padały takie stwierdzenia, jak: „głupota”, „osoba na zdjęciu ma problem z byciem sobą”, „tworzy fałsz”, „udawanie faceta jest iluzją”, „na siłę chce być zaakceptowana” (NT-2020-02-15). W tych wypowiedziach dominuje dezaprobata udawania i pozorowania. Młodzież przyjmująca to podejście podkreślała, że bycie autentycznym należy do wartości cenionych przez rówieśników, a wybrane fotografie zaliczają się ich zdaniem do „wyreżyserowanego” przekazu i tworzenia treści szokujących, zafałszowanych.

W powyższych wypowiedziach można zauważyć wyraźną rozbieżność między dwoma obszarami odbioru fotografii - wewnętrznym i zewnętrznym. W oparciu o to można stwierdzić, że wizualizacja w internecie odbiega od rzeczywistości i wiąże się z symulacją. Profil na Facebooku staje się „miejscem” kreowania siebie. Treści niewerbalne mają wzbudzać społeczne zainteresowanie i służyć przekazowi komunikatów skierowanych do wirtualnej publiczności. Analiza zgromadzonego materiału wykazała, w czym przejawiają się zachowania symulacyjne badanych nastolatek.

\section{Dyskusja wyników i podsumowanie}

Przeanalizowany obszar badawczy stanowi tylko fragment szerszej problematyki związanej z kształtowaniem własnej tożsamości przez młodych ludzi. W tym kontekście warto przywołać badanie Romana Lepperta (2002), który eksplorował rozwój tożsamości i koncepcji siebie u dorastających z perspektywy społeczeństwa naśladowczego. Agnieszka Cybal-Michalska (2006) zajmowała się określeniem kondycji młodego człowieka w świecie zglobalizowanym. Anna Andrzejewska (2014) podjęła temat aktywności w internecie i zagrożeń $\mathrm{z}$ tego wynikających. Także inni badacze wskazują na to, że przestrzeń internetu, będąc dominującym miejscem aktywności dla współczesnej młodzieży, niesie ze sobą liczne zagrożenia (Hejwosz-Gromkowska 2015; Gliniecka 2017). Dotyczy to również wizualnego tworzenia siebie w internecie (Frąckowiak, Rogowski 2009).

W wyniku badania ustalono sposoby wizualnej prezentacji siebie przez nastoletnie użytkowniczki Facebooka. Prezentacje te wyrażają się symulacyjnym kreowaniem swojej tożsamości przez badane nastolatki i pozorowaniem siebie „na chłopaka”. Wydaje się, że ta stylizacja jest warunkowana społecznym oczekiwaniem. Badanie wykazało, że profil tworzony w internecie staje się manifestem pełnym subiektywnego i emocjonalnego przekazu. Nacisk i tworzenie wizerunku 
przyczynia się do kreowania na potrzeby wirtualnej publiczności treści w jednoznacznej wizualizacji siebie. Dzięki badaniu poznano ten sposób przedstawianie siebie z perspektywy samych osób badanych. Analizowany profil w mediach społecznościowych i zafałszowany wizerunek mogą być wpisane w tendencje postmodernistyczne. Możliwe jest w tym względzie zwrócenie uwagi na tymczasowość, wolność wyboru, indywidualizm, płynność struktur, relatywizm. Powyższe analizy skłaniają do przypuszczenia, że kreacja przyjmowana w internecie jest tendencyjnym przekazem i pozą kulturową. Przekaz ten opiera się na treściach niewerbalnych i jest środkiem do publikacji informacji o sobie za pomocą obrazu. Profil tworzony w rzeczywistości wirtualnej oparty jest na udostępnianych/powielanych obrazach, które zawierają określony komunikat. To, co badane nastolatki upubliczniają, to pewna odsłona samych siebie i tylko fragment rzeczywistości. Cyberprzestrzeń może warunkować wycinkowe tworzenie siebie i brak spójności w traktowaniu tego, co jest prezentowane.

Zwrócono uwagę na kilka kwestii związanych $\mathrm{z}$ wizualizacją. W przekazie wizualnym można wyodrębnić nową funkcję obrazu. Fotografie spełniają rolę „tworzenia siebie” i w przypadku przyjmowania symulacji, stają się odrębnym zindywidualizowanym przekazem. Zamieszczane fotografie stają się samoistnym nośnikiem komunikatu wizualnego. Odczytanie określonych treści ma wywoływać jednoznaczną reakcję, opartą na subiektywności. Kulturowe uwarunkowania dotyczą wpływu na audytorium i tworzą wzajemną „grę pozorów”, która wzmaga manipulację i sztuczność.

W kontekście teorii J. Baudrillarda, wirtualną aktywność badanych nastolatek należy zinterpretować jako symulacyjne tworzenie własnej tożsamości. Konstruowanie wizualnego obrazu siebie przy pomocy manipulacyjnych środków i narzędzi potęguje imitację siebie. Obraz tworzony przez badane można zaliczyć do symulakry, czyli procesu pozorującego istnienie czegoś. To udawanie stwarza pozór i przyczynia się do poczucia zagubienia. $Z$ tego względu wizualizacje badanych nastolatek można intepretować jako wytwarzanie sztucznej i negocjacyjnej rzeczywistości. Niezwykle pomocna w tym względzie jest przestrzeń cyberprzestrzeni. Właśnie tam można tworzyć i przyjmować wirtualne maski.

Podjęte badanie wskazuje na to, że tworzona kreacja siebie może prowadzić do tworzenia upozorowanej kultury. Określony sposób prezentacji służy symulacyjnemu tworzeniu własnej tożsamości. Wirtualność uwypukla trudność definicji rzeczywistości obiektywnej i przyczynia się do wchodzenia w wytwarzanie własnego, oderwanego od rzeczywistości obrazu.

Badanie miało charakter eksploracyjny. Na jego podstawie można sformułować kilka wniosków o charakterze pedagogicznym. Istotne wydaje się uchwycenie społecznego konstruowania tożsamości przez młodych ludzi w rzeczywistości wirtualnej. W tym kontekście rodzi się pytanie o zasadność i sens wychowania do pełnienia ról płciowych i ich akceptacja $\mathrm{w}$ codziennym życiu. $\mathrm{W}$ tym względzie wskazaniem pedagogicznym powinna być refleksja dotycząca odkrywania 
i afirmacji własnej płciowości. Wizerunek cielesności prezentowany w mediach może zastępować realny obraz osoby. W obliczu współczesnych przemian obecnych w kulturze może otwierać się perspektywa uświadamiająca próbę redukcji rozumienia cielesności, ponadto negowania płci i sfery biologicznej. A zatem niezwykle istotne wydaje się towarzyszenie młodemu człowiekowi w odkrywaniu tożsamości w każdym jej wymiarze i podejmowanie refleksji nad działaniami zmierzającymi do tego, aby adolescent w obiektywnym wymiarze zapragnął być sobą.

Eksperymenty związane $\mathrm{z}$ tożsamością wpisują się zazwyczaj w okres adolescencji. W związku z tym wydaje się zasadne podejmowanie adekwatnych działań pedagogicznych w obliczu tych eksperymentów. A zatem należy zwrócić uwagę na wspomaganie akceptacji siebie przez młodzież i rozszerzenie refleksji nad rozwojem własnym tożsamości. Uwzględnienie tej kwestii ukierunkowuje na całościowe podejście do rozumienia samego siebie. Nie chodzi jedynie o kreowanie własnego image’u. W kształtowaniu tożsamości może okazać się niewystarczające skupienie uwagi na wizualnym przedstawieniu siebie, które powoduje pozorne „robienie wrażenia”. Takie tendencje można określić, jako „tożsamość zamkniętą w celi wizerunku" (Melosik 2013, s. 99).

Przedstawione przedsięwzięcie badawcze zwróciło uwagę na zjawisko społecznego funkcjonowania fotografii. Tworzenie siebie oparte na kulturze wizualnej staje się sposobem przekazywania informacji przy pomocy obrazu i jest formą komunikatu. Pomocne w tym względzie jest sięganie po przekazy pozawerbalne, które stają się dodatkowym źródłem ukazującym człowieka i wzbogacającym wiedzę na temat współczesnej młodzieży oraz jej aktywności w cyberprzestrzeni. Poznanie obszaru wizualności i odbioru treści pozawerbalnych z pewnością pozwoli na lepsze zrozumienie problemów, z jakimi zmagają się dostrajający. Adolescent znajduje w rzeczywistości cyfrowej przestrzeń, czy wręcz szuka w niej „dowodu na własne istnienie" (Marody 2010, s. 69). Należy podejmować starania, aby w wirtualnym świecie dostrzec młodego człowieka z jego realnymi potrzebami.

\section{Bibliografia}

Andrzejewska A. (2014). Dzieci i młodzież w sieci zagrożeń realnych $i$ wirtualnych. Aspekty teoretyczne i empiryczne. Warszawa: Difin.

Baudrillard J. (2005). Symulakry i symulacja. Warszawa: Wydawnictwo sic!

Brzezińska A., Ziółkowska B., Appelt K. (2016). Psychologia rozwoju człowieka. Gdańsk: Gdańskie Wydawnictwo Psychologiczne.

Czerwińska-Jasiewicz M. (2015). Psychologia rozwoju młodzieży w kontekście biegu zycia. Warszawa: Difin.

Człowiek w obliczu szans cyberprzestrzeni i świata wirtualnego (2014). Bednarek J. (red.). Warszawa: Difin.

Cybal-Michalska A. (2006). Tożsamość młodzieży w perspektywie globalnego świata.

Poznań: Wydawnictwo Naukowe Uniwersytetu Adama Mickiewicza. 
Encyklopedia pedagogiczna XXI wieku (2007). Pilch T. (red.). Warszawa: Wydawnictwo Akademickie „Żak”.

Erikson E.H. (2004). Tożsamość a cykl życia. Warszawa: Zysk i S-ka.

Filiciak M., Danielewicz M., Halawa M., Mazurek P., Nowatny A. (2010). Młodzi $i$ media. Nowe media a uczestnictwo $w$ kulturze. Warszawa: Wyższa Szkoła Psychologii Społecznej.

Giddens A. (2007). Nowoczesność i tożsamość: „ja” i społeczeństwo w epoce późnej nowoczesności. Warszawa: Wydawnictwo Naukowe PWN.

Głażewski M. (2018). Edukacja jako symulakrum. „Forum Pedagogiczne”, nr 1, s. $147-166$.

Gondek J. Zjawisko symulacji we współczesnym społeczeństwie w ujęciu Jeana Baudrillarda. „Człowiek w Kulturze”, nr 26, s. 427-442.

Gromkowska-Melosik A., Melosik Z. (2014). Tożsamość w społeczeństwie współczesnym: pop-kulturowe (re)interpretacje. Kraków: Oficyna Wydawnicza „Impuls”.

Hejwosz-Gromkowska D. (red.). (2014). Rekonstrukcje tożsamości w kulturze natychmiastowości. Poznań: Wydawnictwo Naukowe Uniwersytetu Adama Mickiewicza.

Jemialniak D. (red.). (2012). Badania jakościowe. Metody i narzędzia. T. 2. Warszawa: Wydawnictwo Naukowe PWN.

Kaczorowski B. (red.). (2006). Encyklopedia PWN. Warszawa: Wydawnictwo Szkolne PWN.

Konecki K. (2000). Studia z metodologii badań jakościowych: teoria ugruntowana. Warszawa: Wydawnictwo Naukowe PWN.

Konieczna D. (2014). Analiza dyskursu: w poszukiwaniu tożsamości współczesnej młodzieży. Warszawa: CeDeWu.pl.

Kozinets R.V. (2012). Netnografia. Badania etnograficzne online. Warszawa: Wydawnictwo Naukowe PWN.

Kubinowski D. (2010). Jakościowe badania pedagogiczne: filozofia, metodyka, ewaluacja. Lublin: Wydawnictwo Uniwersytetu Marii Curie-Skłodowskiej.

Kwieciński Z., Witkowski L. (red.). (1990). Ku pedagogii pogranicza. Toruń: Wydawnictwo Uniwersytetu Mikołaja Kopernika.

Leppert R. (2002). Młodzież - świat przeżywany i tożsamość. Studia empiryczne nad bydgoskimi licealistami. Kraków: Oficyna Wydawnicza „Impuls”.

Melosik Z. (2003). Kultura popularna jako czynnik socjalizacji. W: Pedagogika: podręcznik akademicki. Kwieciński Z., Śliwerski B. (red.). Warszawa: Wydawnictwo Naukowe PWN.

Melosik Z. (2010). Tożsamość, ciało $i$ władza w kulturze instant. Kraków: Oficyna Wydawnicza „Impuls”.

Oleszkiewicz A., Senejko A. (2013). Psychologia dorastania. Zmiany rozwojowe $w$ dobie globalizacji. Warszawa: Wydawnictwo Naukowe PWN.

Pink S. (2010). Etnografia wizualna. Obrazy i media: przedstawienie w badaniach. Kraków: Wydawnictwo Uniwersytetu Jagiellońskiego. 
Rubacha K. (2008). Metodologia badań nad edukacją. Warszawa: Wydawnictwa Akademickie i Profesjonalne.

Surzykiewicz J. (2012). Współczesne dziewczyny nie maja problemów? Obraz współczesnych nastolatek $i$ jego znaczenie w pracy edukacyjno-wychowawczej $z$ dziewczętami. Dostępny na https://www.ore.edu.pl/wp-content/uploads/phocadownload/pracownie/wspczesne-dziewczyny-nie-maj-problemw.pdf (otwarty: 12.11.2019).

Szklany sufit: bariery i ograniczenia karier polskich kobiet. Raport z badania. (2003). Budrowska B., Duch D., Titkow A. (red.). Warszawa: Wydawnictwo Instytutu Spraw Publicznych.

Szpunar M. (2016). Kultura cyfrowego narcyzmu. Kraków: Wydawnictwo AGH. Sztompka P. (2005). Socjologia wizualna. Fotografia jako metoda badawcza. Warszawa: Wydawnictwo Naukowe PWN.

Techno-widzenie: media i technologie wizualne w społeczeństwie ponowoczesnym. (2014). Rogowski Ł. (red.). Poznań: Wydawnictwo Naukowe Wydziału Nauk Społecznych Uniwersytetu Adama Mickiewicza.

Titkow A. (2002). Interes grupowy polskich kobiet. W: Kobieta w Polsce na przełomie wieków. Nowy kontrakt płci? Fuszara M. (red.). Warszawa: Wydawnictwo Instytutu Spraw Publicznych.

Wadsworth, B. (1998). Teoria Piageta: poznawczy i emocjonalny rozwój dziecka. Warszawa: Wydawnictwa Szkolne i Pedagogiczne.

\title{
VISUALISATION AS A SIMULATED SELF-CREATION IN SOCIAL MEDIA
}

\begin{abstract}
The purpose of the article is to report ways young people self-present on Facebook. Based on the theory by Jean Baudrillard's simulacrum, it was assumed that these presentations serve to simulate creating your own identity. The study used the online-resource method, with a particular emphasis on visual ethnography. The presented research is part of the problems related to building the identity of contemporary youth and trends of post-modern culture. It has been shown that visual content is not only an element of young people detachment from reality, but it is also fictitious. This is especially evident in the virtual forms of activity and content young people post online.
\end{abstract}

Keywords: visualisation; identity; simulacrum; simulated culture. 